Historic, Archive Document

Do not assume content reflects current scientific knowledge, policies, or practices. 



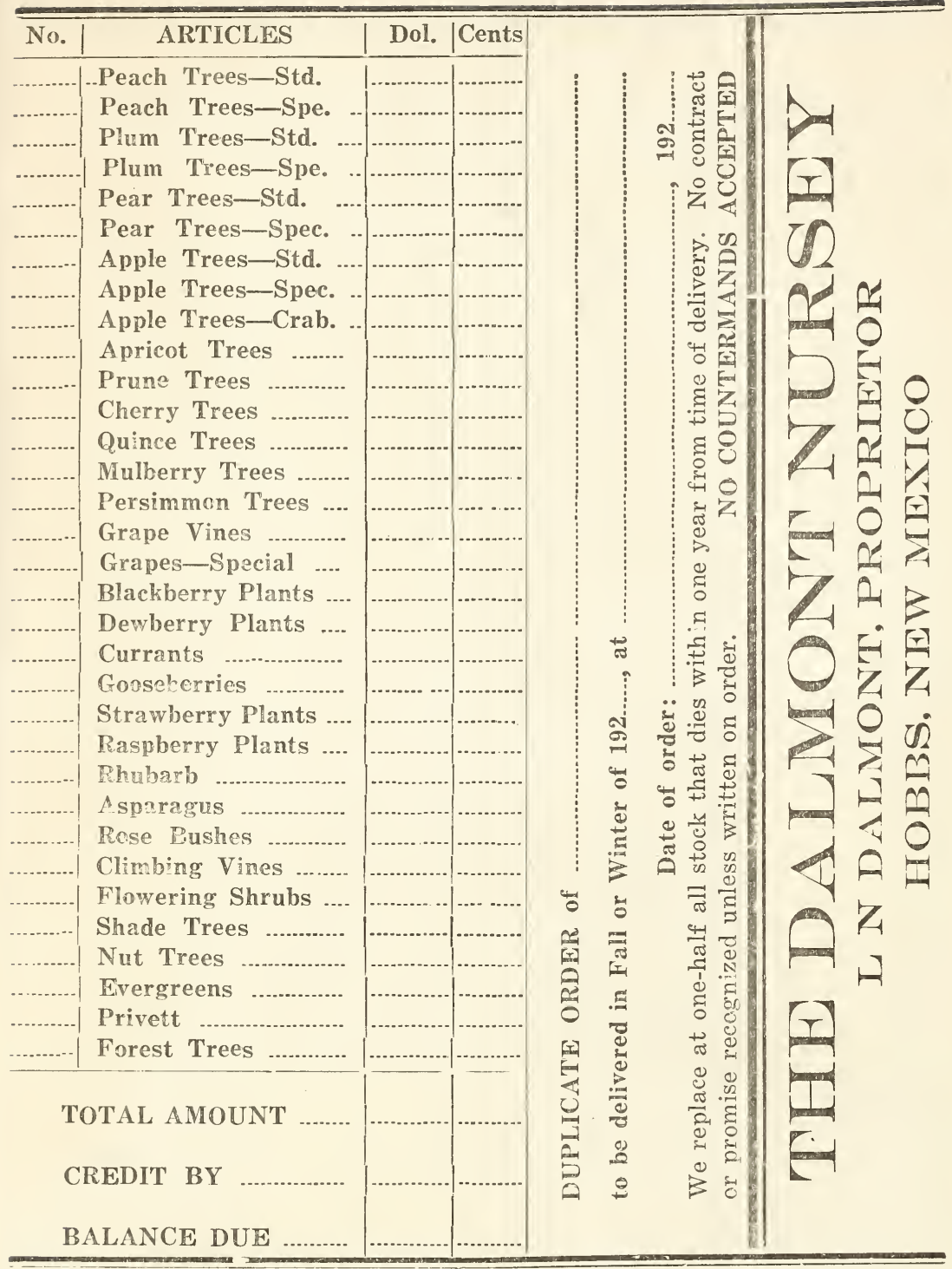

\title{
Handling Fruit Trees in the West Texas and New Mexico Section
}

\author{
BY L. N. DALMONT
}

Shall we make the fruit interest of have been pianted and cared for alWest Texas and New Mexico a suc- most until in bearing; then the owner cess or failure?

There is nothing more disappoint- the weeds, insects, disease and rabing than to see how some people are bits.

neglecting their orchards. It re- Nothing can be achieved without minds us of a balky team pulling a an effort, and in the case of fruit heavy load nearly to the top of the growing constant vigilance is the hill, then slacking up and letting the price of success. We find that the wagon roll back into a ditch where pecple of the Plains need a great dea they never can start it again.

Many orchards over the country orchard and how to take care of it. 
The system which some people follow, which is sure to end in failure, is about like this.

They buy trees where they can get them cheapest, regardless of whether they are varities adapted to the climate, whether they are shaped $u$ pto suit the climate or whether they are healthy or not. Then they plant their trees without thoroughly preparing the soil. They prune them high, wnich causes them to become top heavy, get leaned to the northeast, which exposes the body of the tree to the hot sun. The body of the tree becomes sun blistered, the borer fly inserts its eggs in the body of the tree, the moisture that oozes out of the cracks keeps the eggs alive till they hatch. When the worm hatches it works it way into the body of the tree, generally working down until it gets on a level with the soil. The tree is finally weakened so that the result is failure. The borer will not get into a healthy tree, where the bark is smooth and sound, as the borer worm works about the same as the screw worm fiy does on stock; it has to have a wounded place to insert its eg.gs.

The next hardship that the tree is subjected to is the want of cultivation, many times being neglected till probably June or July. When the weeds are about full grown and have gone to seed the owner decicies that it is about time that he was doing something for his orchard. He concludes that about the only thing he can do is to take two horses and a turning plow and turn them under. The ground by this time has generaIiy become hard by dry weather and being sapped with weeds. He has to plow from six to eight inches deep, breaking the grounr up in clods from the size of an egg to a man's head. This breaks up the roots of the trees at a time when the tree can least overcome the injury incident to such cultivation.

It also lets the sun and air into the soil, so that it dries out deeper than if it had not been plowed at all. We should never break an orchard over four or five inches deep close to the tree after it is as much as two or three years old. This should be done in the dormant season, so that if any roots are broken they can callous in the winter and start new roots in the spring. If we should neglect the orchard until the weeds have gotten large and the ground has become hard, we shculd never plow it with anything that opens up the soil or tears up the roots, but rather take some kind of disc harrow and pulverize the weeds and the top of the soil, so as to have a mulch on the top of the ground which will retain the moisture.

Another damage that a great many trees are subject to is the depredation of cattle and rabbits. If any trees have the hardihood to resist all this, they finish them up by sowing rye or wheat among them in winter and sap the trees of the moisture and plant feed they should have in the spring.

When we consider a few cents in the price of a good tree, that has the possibility of being a failure after taking care of it long enough to come into bearing, the consideration is very small compared with the value of what a good tree is worth and the disappointment of a worthless tree.

\section{Pruning the Tree}

Wrong system in pruning is the cause of the destruction of many good trees. We have more sunshine and hard winds here than most anywhere else, and we must learn to prune our trees to suit the climate. This must first be done by getting trees that have been shaped up in the nursery row. We would recommend, preferably, good two or three-yearcld trees which have not been pruned more than from 12 to 16 inches in the nursery.

The accompanying illustration shows the method of pruning roots so as to make a cut that will be turned down when the trees are set.

We do not advise root pruning with the view of shortening the roots, but just to cut the roots back to where thev are sound and sappy, so they rxill callous and start new roots as if they had never been dug up. Then set in holes inclining them very slightly to the southwest, with the lowest and best limbs turned to the southwest. The tree may be set Iittle deeper in the orchard than is stood in the nursery. Great care should be taken in shaping the frame for the top of the tree, so as to grow a tree that will keep halanced a gainst the hard southwest winds, and shade it self. The sun should never shine on the body of a fruit tree, and the shade should always be arcund the roots, in order that the soil might be liept moist and cool in hot dry weather.

This can be done by first pruning the northeast side of the tree anywhere from six to eight inches higher than the south and west. Have yonr bcs and lorvest limbs on the southwest; about, 12 or 14 inches above the ground; your second limb about two or three inches higher on the south side of the tree; vour third limb two or three inches higher on the southeast; your fourth limb two or three inches higher on the northeast; your fifth limb two or three inches 


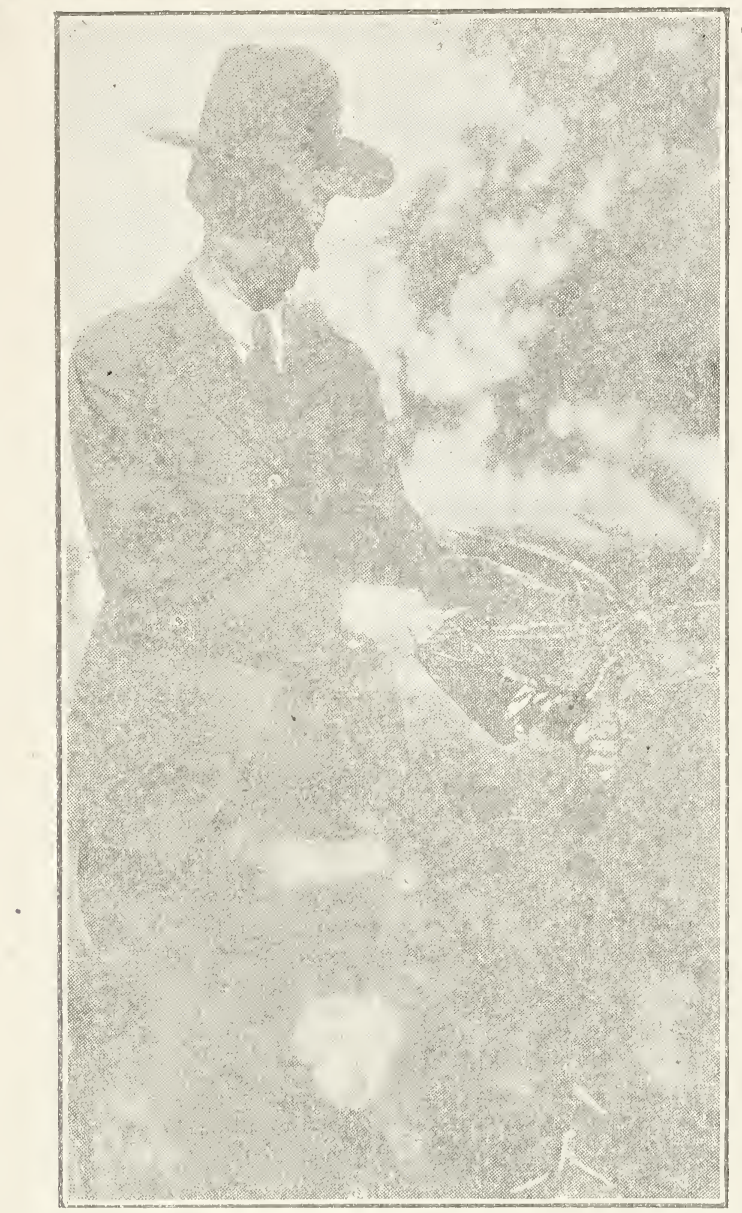

Showing How the Roots Should be Pruned

higher to the northwest; your sixth limb two or three inches higher back to the southwest; your seventh limb two or three inches higher back to the south. Leave from eight to twelve stubs or limbs to start the frame or head of your trees. Then cut the body above the last limb, cutting from the north to the south, having all limbs cut back to stubs anywhere from three to five inshes long. Cut from the north to the south side when there is a bud on the south. The bud at the top of the limb will continue the growth, and loeing on the south side, will naturally be inclined that way and resist the force of the wind better.

Never start a forked tree; neither start all your limbs in a bunch or close together, but let the body of the tree come up, above all the limbs. Alternate the limbs from the southwest around the body of the tree, each time having the limb a little higher and further around the tree. If you grow a forked tree, or the limbs come out in a bunch, they will be so near of equal size that when they are loaded with fruit the weight of the fruit will pull in opposite directions to each othef, and when it comes a storm your tree is liable to split and be badly damaged.

\section{Preparation of the Soil}

Now, in reference to the preparatin of the soil we would decommend that the soil be well broken the season before planting and cultivated in a light legume crop, such as peas. We would recommend that the last time the ground is broken it be broken in lands the distance apart that the trees are going to be planted and the water furrow be broken the secand time. a strip of five or six feet wide as deep as two or three horses can pull a $1 \overline{0}$-inch turning plow. Then run a harrow over the soil so as to pulverize it. This will relieve the necessity of digging large holes. Plant in the water furrow, but hill up 
around your trees; this can be done wit ha turning plow after trees are set, so that the water will not stand closer than two or three feet, but rather have moisture soak to the trees. Never neglect to cultivate your orchard. It is best to shape it so you can cultivate both ways.

There is a general opinion that trees must be pruned some time in the year, generally supposed to be in the spring. This may be true and it may not. Examine your trees, and if they need prinning, prune them today. Nu necessity to wait for any reason, but the sooner the better. We should not wait tiil t limb gets as large as a pencil or a broom stick to cut if off.

If you have a bud or twig where vou do not want a limb. shave or rub it off. Let that much growth go where you want it instead of a limb to be cut.

I would not advise pruning in hot dry weather, as the cut will dry out fast and not heal over as well. Nor is it best to prune when an excessive amount of sap is up, as the bark is more apt to peel back, and expose more of the wound. But any time during the moderate growing season will do to prune trees. A cut will heal over better in the growing seasonj as we have a high altitude and a great deeal of sunshine. Our trees can be denser than in most any other country. We need to prune somethes if the trees are so dense that the sunshine can not get to the fruit or there are crooked limbs that interfere or rub each other.

Miost of the fruit crops grown in this country grows on limbs from one foot to six feet above the ground. Most of the bearing wood is cut off by the way some people prune. It sometimes occurs that fruit can not stay on the top limbs during the windy season.

There is no necessity of making a failure. Start right and stay right. Start right by planting good varieties adapted to the climate, prune right and cultivate. I think we can grow fruit with as little moisture as kaffir corn, even with as little cultivation, however, cultivation is very important.

This does not apuly to shade trees, as they have thick bark and can stand the hot sun.

I am often asked, "Which is the best time to plant trees-fall or spring?" I will say that it depends on the season. If the soil is wet and the air damp, fall is better, as the soil will get packed around the roots and the roots will callous through the winter and start new roots in the early spring long before the sap rises. Trees handled in this way will make a better growth and stand dry weath- er much better than trees planted late.

Sometimes we have a dry, windy winter, that has a tendency to dry nut the tops before the roots start. In this case it might be better to plant in early spring, about the last of February.

There is a method that is safer than either of these. Dig trees in the fall (trees will do better dug in the fall), cut the roots just as if vou were going to plant them, and then heel them to about 14 inches deep, and lean the tops to the south at an ancle of about 75 degrees. Cover the rcots withh fine soil, pour in enough water to make them moist through the winter, and cover the tops about two feet with dry soil. Then plant abrut the 20th of February. Do not expose the roots to dry air. While you are planting this way, the roots will start during the winter, and the trees will stay in good condition. Care must ha taken to cover the roots deep enough.

The brst way to handle srapes and berries is to plant in the fall. Plant a little deeper than they were in the nursery. After they aer planted, cut if all the top within two inches of the ground. A new top will grow better than the old one. In the spring it is likely that several shoots will start. Cut them all off the grapes but one, and train this one on a trelis just as soon as possible. Blackberry stalks should be cut down each season just as soon as they get hrnum fruiting, and let the new sta'l's bear the next year.

Freroreens will grow better when toron win with a ball of dirt around the roots and a burlap sewed around the ball. so as to keen it from crumbling. Set in holes, leave burlap on, and fill around ball with loose dirt: then water envugh to settle soil, and then hill up with loose soil. Put box or barrel around them with both ends out; line between barrel and evergreen with some kind of moist packing-straw, moss or sacks that have been soaked. Keep moist by sprinkling of evenings, but do not keep too wet. Keep this up until the hard, dry winds are over in the spring. Do not keon soil arnund the roots too wet, water well about once each week. Keep packing in barrel moist, but not too wet.

Everblooming roses will do better cut off within four inches of the gronind and covered with some kind of light mulch in the winter.

In making these suggestions. I do not mean to tell or to know all that should be known about fruit culture, but hope to be some help to the inexperienced, that we may make the West more beautiful and fruitful. 